\title{
Efficacy evaluation of empty palm oil fruit bunch compost in improving soil characteristics, plant growth and disease suppression of tomato plants under tropical acid soil
}

\section{Authors Info}

Mukhlis', Mohd. Razi Ismail', Halimi Mohd. Saud', S.H. Habib', H. Kausar ${ }^{2.3}$, M. A. Maleque ${ }^{4}$ and M.A. Hakim ${ }^{2,5}$

'Deptt. of Agriculture Technology, Faculty of Agriculture, University Putra Malaysia, 43400 Serdang, Malaysia

'Lab. of Food Crops, Institute of Tropical Agriculture, University Putra Malaysia, 43400, Serdang, Malaysia

${ }^{3}$ Deptt. of Agroforestry \& Environmenta Science, Faculty of Agriculture, Sher-eBangl Agricultural University, Dhaka-1207, Bangladesh

${ }^{4}$ Department of Environment, Sher-e-Banglanagar, Dhaka, 1207, Bangladesh

${ }^{5}$ Deptt. of Agricultural Chemistry, Hajee Mohammad Danesh and Technology University, Dinajpur-5200, Bangladesh

*Corresponding Author Email :
razi@upm.edu.my

Key words

Disease resistance,

EFB compost,

Lycopersicon esculentum,

Soil properties

Publication Info

Paper received: 18.02 .2016

Revised received: 19.04 .2016

Accepted : 30.04 .2016

\section{Abstract}

Aim : Tomato is one of the most important crops worldwide as it is the second most important vegetable in the world after potato. A study was conducted to investigate the efficacy of empty fruit bunch (EFB) compost in improving soil characteristics, plant growth and disease suppression of tomato plants under tropical acid soil.

Methodology : Twelve tomato seedling cv MT-11 were transplanted on each planting bed. The growth of tomato plant was assessed based on plant height, leaf area, dry matter weight and incidence of bacterial wilt disease. Soil sampling was done at 45 and 60 day after transplanting (DAT) for physio-chemical and microbial properties.

Results : Applying EFB compost increased plant height, leaf area, dry matter accumulation, and suppressed development of bacterial wilt disease compared to using chicken manure. A higher disease reduction (16.7\%) occurred with $15 \mathrm{mg} \mathrm{ha}^{-1} \mathrm{EFB}$ compost, followed by $22.5 \mathrm{mg}$ ha ${ }^{-1} \mathrm{EFB}$ compost (14.3\%), and $7.5 \mathrm{mg} \mathrm{ha}^{-1} \mathrm{EFB}$ compost $(8.33 \%)$.

Interpretation : Organic amendment in tomato cultivation affects soil properties, plant development and disease suppression. Application of EFB compost at $15 \mathrm{mg} \mathrm{ha}^{-1}$ appeared as the best treatment soil amendment in tomato cultivation under tropical acidic soil condition.

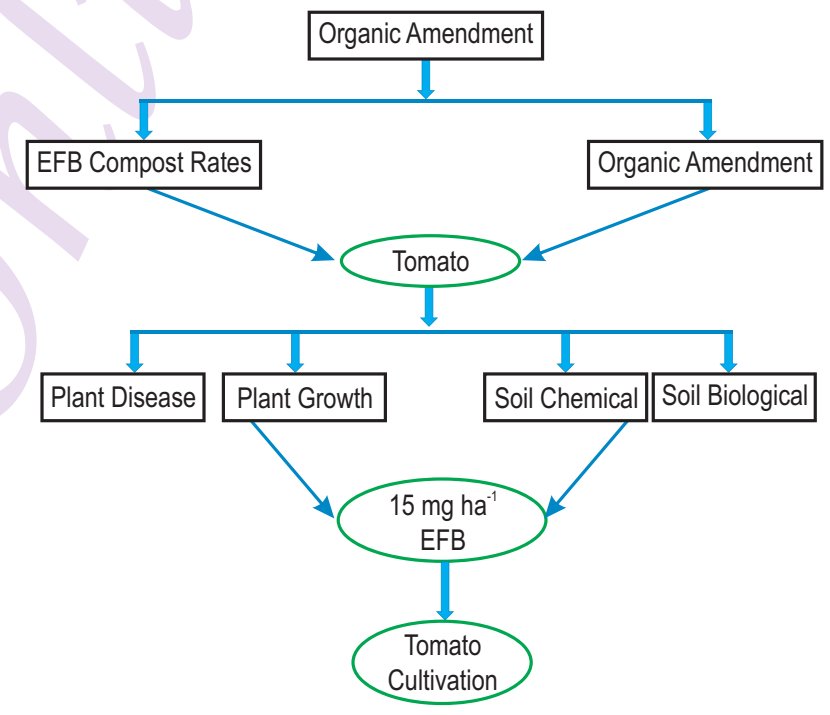




\section{Introduction}

Tomato (Lycopersicum esculentum) is one of the most widely distributed vegetables grown in various cropping systems and locations throughout the world. Tomato is the mainfruit vegetable for low-income oriented farmers, and a valuable cash crop in the tropics and subtropics. Tomato yield has declined during last few years due to intensive crop cultivation, gradual deficiency in soil organic matter, accumulation of phytotoxic substances and pests and diseases infestation (Pinheiro et al., 2006). However, application of empty fruit bunch compost has reported significant increase in tomato yield, plant dry weight and biomass production (Mokhtari et al., 2013) and has reduced total $\mathrm{N}$ fertilizer requirements (Cassman et al., 1998).

Demand for organic fertilizer and interest of utilizing agricultural wastes and converting the wastes into value added fertilizers are increasing gradually for the conservation of natural resources, lessening the input cost of farmers as well as maintenance of environmental quality (Biradar and Biradar, 2015). The empty fruit bunch are organic residue that results after the fresh fruit bunches are harvested from the oil palm and is processed in the mill. About $22 \%$ of the fresh fruit bunch processed ends up as empty fruit bunch which is a good source of macro and micro nutrients. Normally, empty fruit bunch contains $30 \%$ dry matter, $2.5 \%$ oil, and $63 \%$ water and is a fibrous material. Even when it is pied up to more than $1.5 \mathrm{~m}$ in height, the bottom mass remains loose and porous, allowing air to pass freely through the pile. Therefore, EFB is considered suitable for the production of good quality compost (Good and Beatty, 2011; Mohammadi etal., 2012).

Most of the soils in Malaysia are Ultisols and Oxisols and occupy about $72 \%$ of Peninsular Malaysia. These soils are highly leached, acidic deficient in nitrogen, and frequently contain toxic concentrations of available aluminium and manganese (Lal, 2000). Agricultural wastes have long been utilized to upgrade soil fertility and crop productivity in various ways (Marinari et al., 2000; Zhai et al., 2009). Soil organic matter and essential plant nutrients are added for plant growth (Yang et al., 2004). Several studies have demonstrated that EFB compost can be applied to agricultural land as a substitute for chemical fertilizers and for soil conditioning (Thambirajah et al., 1995; Yusri et al., 1998; Zhai et al., 2009; Noor Mohammad et al., 2012). Research on field application of EFB compost for the understanding of crops response in acid tropical soils is lacking. Therefore, a field experiment was conducted to investigate the efficacy of EFB compost in improving soil characteristics, plant growth and disease suppression of tomato plants under tropical acid soil.

\section{Materials and Methods}

Experimental site and treatments : An experiment was carried out in Experimental Farm 10, Faculty of Agriculture, UPM Serdang from January-May 2014. The soil type was Munchong series which was sandy clay loam, acidic, low in organic matter, and poor in macro nutrients. Land was prepared by clearing weeds and plowing twice, followed by the preparation of planting-bed. Each $1 \mathrm{~m} \times 3 \mathrm{~m}$ planting-bed was separated by a distance of $1 \mathrm{~m}$. There were four treatments of EFB compost rate: $0 \mathrm{mg} \mathrm{ha}^{-1} \mathrm{EFB}$ compost (Control), $7.5 \mathrm{mg} \mathrm{ha}^{-1}$ EFB compost, $15.0 \mathrm{mg} \mathrm{ha}^{-1}$ EFB compost, $22.5 \mathrm{mg} \mathrm{ha}^{-1}$ EFB compost and $7.5 \mathrm{mg} \mathrm{ha}^{-1}$ chicken manure. Chicken manure was used as farmers' standard. The experimental design used was as a randomized completely block design with three replications.

A 28-day-old empty fruit bunch compost supplemented with Trichoderma T24 and chicken manure with specific properties was used (Table 1). Seventy five kg empty fruit bunch and $30 \mathrm{~kg}$ chicken manure were mixed properly. The materials were then inoculated with $10.5 \mathrm{~kg}$ of Trichoderma T24 inoculum. A half of inoculums were added at beginning of composting process and the remaining was done after 18 days of composting when temperature in the heap decreased. The substrates were taken into 10 Styrofoam containers which contained $10 \mathrm{~kg}$ of materials. The temperature of composting materials was monitored daily and the heaps were turned every other day for 28 days. Water was added to the heap, if the material moisture was lower than $60 \%$ (Kausar et al., 2010; 2011).

Planting and crop management : The experimental units were planted with tomato cv. MT-11. Tomato seedlings were germinated and grown in polystyrene trays filled with potting mix. Ten days after sowing, tomato seedlings were transplanted into small planting bags (10 $\mathrm{cm}$ in diameter) and watered as needed with tap water. Twelve seedlings ( 30 day-old) per treatment were transplanted to the field in double rows $60 \mathrm{~cm}$ apart, at a distance of $50 \mathrm{~cm}$ in between rows, on each planting bed. All the plants were fertilized with NPK (12:12:17) @ $12.5 \mathrm{~g} \mathrm{plant}^{-1}$ as basal fertilizer (equal to $0.5 \mathrm{mg} \mathrm{ha}^{-1}$ ). The whole plot was watered once in the morning and again in the late afternoon by means of a sprinkler system. Weed control was done manually.

Plant performances sampling and related data : The growth of tomato plant was studied based on plant height, leaf area, dry matter weight, and incidence of bacterial wilt disease. Plants were sampled 45 and 60 days after transplanting (DAT). The whole plants were uprooted and weighted. For measuring total leaf area, leaves were individually separated from the plant and total leaf area was determined using LI-3100 Leaf Area Meter. The samples were oven dried at $60{ }^{\circ} \mathrm{C}$ until constant weight was attained. After estimating dry weight, the samples were ground to a size less than $2.0 \mathrm{~mm}$ and used for determination of $\mathrm{N}, \mathrm{P}, \mathrm{K}, \mathrm{Ca}$ and Mg uptake by plant.

Soil sampling and data collection : Soil sampling was done at 45and 60DAT. Soil was randomly collected from around the tomato plant at a depth of $15 \mathrm{~cm}$ using small auger. Part of soil sample was stored in a freezer at $4^{\circ} \mathrm{C}$ for determination of 
bacteria, fungi and Trichoderma population, as well as $\mathrm{NH}_{4}$ $\mathrm{N} / \mathrm{NO}_{3}-\mathrm{N}$ content. While the remaining was air dried and sieved to a size less than $2.0 \mathrm{~mm}$ for chemical analysis.

Chemical analysis of soil : The $\mathrm{pH}$ was measured by following the method of Sharifuddin and Dynoodt (1981). Two g of soil was analyzed for total soil carbon using Total $\mathrm{C}$ method (computerized system model Leco CR-412), using infra-red absorption and $99.5 \%$ pure oxygen at $40 \mathrm{psi}$ at $1500 \mathrm{o} \mathrm{C}$ for $60-120 \mathrm{sec}$ nominal. Kjeldahl method was used to determine total N. Extractable NH4$\mathrm{N}$ and NO3-N concentration were determined by the modified method of Keeney and Nelson (1982). Molybdenum blue method was used to determine extractable P using the method of Murphy and Riley (1962). Leaching method was adopted to determine exchangeable K, Ca, and Mg (Sharifuddin and Dynoodt, 1981).

Bacterial wilt disease incidence of tomato plant : The symptom of bacterial wilt disease caused by Ralstoniasolan acearum is characterized by sudden wilting of the foliage. Bacterial wilt was distinguished from the vascular disease caused by pathogens by suspending a clean section of diseased stem in clear water, when a white, milky stream of bacterial ooze would exude from the xylem elements in 3-5 min. The water would become completely milky in 10-15 min if the stem had been severely infected. Bacterial wilt disease incidence was counted based on the number of plant infected divided by the total number of plant.

Soil microbial population : Total bacteria, fungi and Trichoderma populations in soil were determined by total plate count technique.

Data analysis : The obtained data were analyzed using SAS package (SAS Institute Inc., 2001) for analysis of variance and mean comparisons by least significant difference.

\section{Results and Discussion}

Different rates of EFB compost evaluated in the present study varied in diverse traits. The study demonstrated that growth and disease suppression of tomato plant increased significantly in term of leaf area, dry matter accumulation, nutrients and bacterial disease infestation with the application of EFB compost or chicken manure. Among the treatments, $15.0 \mathrm{mg} \mathrm{ha}^{-1} \mathrm{EFB}$ compost emerged as the most suitable compost rate for tomato cultivation. The same rate $\left(7.5 \mathrm{mg} \mathrm{ha}^{-1}\right)$ of EFB compost showed comparatively higher performance in most of the studied parameters than that of chicken manure, indicating that EFB compost could be used successfully as soil conditioner for tomato cultivation.

Results showed that leaf area and plant dry weight of tomato at 60 DAT were significantly $(p \leq 0.05)$ influenced by EFB compost and chicken manure. The highest significant leaf area $\left(1854.30 \mathrm{~cm}^{2}\right)$ was found in plants treated with $22.5 \mathrm{mg} \mathrm{ha}^{-1} \mathrm{EFB}$ compost, which was $31 \%$ higher than control $\left(1282.90 \mathrm{~cm}^{2}\right)$. It was noted that plants receiving $7.5 \mathrm{mg} \mathrm{ha}^{-1}$ EFB compost produced $15.46 \%$ higher leaf area and $20.002 \%$ higher dry matter than plants receiving of $7.5 \mathrm{mg} \mathrm{ha}^{-1}$ chicken manure (Table 2).

In the study, EFB compost enhanced plant growth, dry matter accumulation and disease suppression by improving soil physical, chemical and biological properties. Compost consist of humus which is a negatively charged colloidal particle that coagulates with cations and soil particles to form granular or crumb structures. Compost also contains peptides, amino acids, polysaccharides and phytohormones which are available for immediate uptake and absorption by plants (Parradoet al., 2008; Killi and Kavdır, 2013). It improves different physico-chemical properties of soil such as buffering capacity, infiltration rate, prevents rapid changes in acidity or alkalinity, modifies color, and increases heat absorbing capacity that ultimately results in better plant growth and yield (Ouedraogo et al., 2001; Kausar et al, 2014). The coconut coir dust amended with oil palm frond compost provided optimum plant growth condition of cauliflower in a tropical humid soil throughout the growing period due to superiority in physiological traits such as stomatal conductance, photosynthesis rate and chlorophyll content in leaves and higher rate of nutrients uptake resulting maximum total dry mass production and economic yield (Erwan et al., 2013). Use of EFB compost on Brassica rapa var. parachinensis gave higher yield $\left(36.0 \mathrm{mg} \mathrm{ha}^{-1}\right)$ than conventional fertilizers which yielded $34.0 \mathrm{mg}$ ha $^{-1}$ (Chiew, 2004).

Observation on disease infestation showed that bacterial wilt disease incidence was $41.66-66.67 \%$ and $83.33-100 \%$ at 45 and 60 DAT, respectively. The $(p \leq 0.05)$ highest significant disease suppression was found in plants treated with $15.0 \mathrm{mg} \mathrm{ha}^{-1}$ EFB compost both at 45 and 40 DAT, where disease suppression was 60 and $20 \%$ higher than the plants receiving control treatment(Table 2).

Tomato variety MT11used in the study was susceptible to bacterial wilt disease (MARDI, 1990) and most of the plants wilted after day 60 . Bacterial wilt incidence of tomato plants indicaties that the EFB compost was insufficient to suppress the disease, although lowest bacterial infestation was found in plants receiving $15.0 \mathrm{mg} \mathrm{ha}^{-1} \mathrm{EFB}$ compost. The results of the present study were consistent with the findings of Wang et al. (1998) who stated that resistance may often break down or may not be expressed under certain environmental conditions and insufficient for use in heavily infested fields.

Nutrients uptake by tomato plants was significantly $(p \leq$ 0.05 ) influenced by the application of EFB compost and chicken manure, except for potassium. Application of EFB compost and chicken manure increased the uptake of $\mathrm{N}, \mathrm{P}, \mathrm{Ca}$ and $\mathrm{Mg}$. There was no significant difference among the three rates of EFB 
Table 1 : Properties of microbial infused EFB compost and chicken manure

\begin{tabular}{lll}
\hline Parameter & EFB compost & Chicken manure \\
\hline pH & $8.05 \pm 0.31$ & $9.21 \pm 0.58$ \\
Total carbon (\%) & $31.6 \pm 0.44$ & $28.27 \pm 0.39$ \\
Total nitrogen (\%) & $1.76 \pm 0.07$ & $4.04 \pm 0.07$ \\
C/N ratio & $17.95 \pm 0.18$ & $6.99 \pm 0.09$ \\
Electrical conductivity $\left(\mathrm{mS} \mathrm{cm}^{-1}\right)$ & $2.37 \pm 0.05$ & $5.4 \pm 0.26$ \\
$\mathrm{P}(\%)$ & $1.52 \pm 0.05$ & $2.15 \pm 0.04$ \\
$\mathrm{~K}(\%)$ & $1.65 \pm 0.08$ & $2.26 \pm 0.15$ \\
$\mathrm{Ca}(\%)$ & $2.39 \pm 0.13$ & $2.17 \pm 0.08$ \\
$\mathrm{Mg}(\%)$ & $1.02 \pm 0.11$ & $1.48 \pm 0.06$ \\
Total fungi (log10 cfu g- ${ }^{-1}$ compost) & $9.32 \pm 0.15$ & $5.74 \pm 0.04$ \\
Total bacteria (log10 cfu g compost) $_{\text {Total actinobacteria (log10 cfu g }}^{-1}$ compost) & $6.16 \pm 0.14$ & $6.56 \pm 0.45$ \\
\hline
\end{tabular}

Table 2 : Effect of EFB compost and chicken manure on growth at 60 DAT and incidence of bacterial wilt disease of tomato plant

\begin{tabular}{llllll}
\hline $\begin{array}{l}\text { Treatment } \\
\left(\mathbf{m g ~ h a} \mathbf{~}^{-1}\right)\end{array}$ & $\begin{array}{l}\text { Plant height } \\
(\mathbf{c m})\end{array}$ & $\begin{array}{l}\text { Leaf area } \\
\left.\mathbf{( c m}^{2}\right)\end{array}$ & $\begin{array}{l}\text { Dry matter } \\
\text { weight }(\mathbf{g})\end{array}$ & $\begin{array}{l}\text { Bact. Wilt 45 } \\
\text { DAT }(\%)\end{array}$ & $\begin{array}{l}\text { Bact. Wilt 60 } \\
\text { DAT }(\%)\end{array}$ \\
\hline $0.0 \mathrm{EFB}($ Control) & $60.03^{\mathrm{a}}$ & $1282.90^{\mathrm{c}}$ & $22.00^{\mathrm{c}}$ & $66.67^{\mathrm{a}}$ & $100.00^{\mathrm{a}}$ \\
$7.5 \mathrm{EFB}$ & $63.40^{\mathrm{a}}$ & $1823.60^{\mathrm{a}}$ & $35.40^{\mathrm{a}}$ & $55.56^{\mathrm{b}}$ & $91.67^{\mathrm{ab}}$ \\
$15.0 \mathrm{EFB}$ & $65.93^{\mathrm{a}}$ & $1844.50^{\mathrm{a}}$ & $36.90^{\mathrm{a}}$ & $41.66^{\mathrm{a}}$ & $83.33^{\mathrm{b}}$ \\
$22.5 \mathrm{EFB}$ & $67.53^{\mathrm{a}}$ & $1854.30^{\mathrm{a}}$ & $38.37^{\mathrm{a}}$ & $47.22^{\mathrm{a}}$ & $85.66^{\mathrm{b}}$ \\
$7.5 \mathrm{CM}$ & $63.00^{\mathrm{a}}$ & $1579.30^{\mathrm{b}}$ & $29.49^{\mathrm{b}}$ & $55.55^{\mathrm{b}}$ & $100.00^{\mathrm{a}}$
\end{tabular}

Different letters in a column indicate significant difference at $P \leq 0.05$ by LSD; EFB $=$ empty fruit bunches, $C M=$ chicken manure, DAT= days after transplanting, Bact. Wilt= bacterial wilt disease

compost and chicken manure, except for Mg. The highest amount of $\mathrm{Mg}$ and $\mathrm{K}$ was found in plants receiving $15.0 \mathrm{mg} \mathrm{ha}^{-1} \mathrm{EFB}$ compost which was closely followed by $22.5 \mathrm{mg} \mathrm{ha}^{-1}$ EFB compost, $7.5 \mathrm{mg} \mathrm{ha}^{-1}$ EFB compost and $7.5 \mathrm{mg} \mathrm{ha}^{-1}$ chicken manure, respectively (Table 3 ).

The increase in crop growth was reflected by nutrients uptake of tomato plants. It was found that $\mathrm{N}, \mathrm{P}, \mathrm{K}, \mathrm{Ca}$ and $\mathrm{Mg}$ contents in tomato plant increased significantly with the applications of EFB compost. Organic molecules in EFB compost act as sites for cation exchange and increase adsorption and retention of nutrients in soil. Organic acids and humic fractions form compounds with phosphorus and zinc making them available to plants. Humic acid increases extractability of iron, manganese, zinc, and copper, but this extractability decreases gradually with time. These substances reduce aluminum toxicity but increase availability of iron and manganese by reducing their higher oxide forms to available forms (Kausar et al., 2014).

Total carbon content in soil was significantly $(P \leq 0.05)$ influenced by the application of EFB compost and chicken manure. Total carbon content increased with increasing the rate of EFB compost. At 60 DAP, the highest amount of total carbon was found in soil receiving $15.0 \mathrm{mg} \mathrm{ha}^{-1} \mathrm{EFB}$ compost. There was no significance difference between EFB compost and chicken manure at the same rate $\left(7.5 \mathrm{mg} \mathrm{ha}^{-1}\right)$ for total carbon. The total $\mathrm{N}$ content increased with increase in EFB compost rate. At the same rate $\left(7.5 \mathrm{mg} \mathrm{ha}^{-1}\right)$, the effect of EFB compost on total $\mathrm{N}$ as compared to that of chicken manure was high (Table 4).

The highest amount of $\mathrm{NH}_{4}-\mathrm{N}$ was found in soil treated with $22.5 \mathrm{mg} \mathrm{ha}^{-1} \mathrm{EFB}$ compost which was statistically at par with the soil receiving $15.0 \mathrm{mg} \mathrm{ha}^{-1} \mathrm{EFB}$ compost and $7.5 \mathrm{mg} \mathrm{ha}^{-1} \mathrm{EFB}$ compost. Application of EFB compost or chicken manure significantly $(\mathrm{P} \leq 0.05)$ increased the soil content of $\mathrm{NO}_{3}-\mathrm{N}$ at 60 DAT. At the same rate, application of EFB compost significantly $(\mathrm{P} \leq 0.05)$ increased the soil content of $\mathrm{NO}_{3}-\mathrm{N}$ as compared to chicken manure. The increase of EFB compost rate significantly $(P \leq 0.05)$ increased the amount of extractable $P$. At both sampling dates, same rate $(7.5 \mathrm{mg}$ ha 1$)$ of EFB compost and chicken manure were statistically similar in terms of extractable $P$. EFB compost and chicken manure significantly influenced $(P \leq 0.05)$ the amount of exchangeable $K$ in soil. The amount of exchangeable $\mathrm{K}$ increased with increase of EFB compost rate. However, there was no significant difference in between $15.0 \mathrm{mg}$ $\mathrm{ha}^{-1}$ and $22.5 \mathrm{mg} \mathrm{ha}{ }^{-1}$ EFB compost rate. The amount of exchangeable $\mathrm{K}$ was higher in soil treated with $7.5 \mathrm{mg} \mathrm{ha}^{-1} \mathrm{EFB}$ compost than soil treated with same rate of chicken manure. Use of EFB compost significantly $(P \leq 0.05)$ influenced the amount of exchangeable $\mathrm{Ca}$ in soil. The highest amount of exchangeable $\mathrm{Ca}$ 
Table 3 : Effect of EFB compost and chicken manure on nutrient uptake of tomato plant at 60 DAT

\begin{tabular}{llllll}
\hline $\begin{array}{l}\text { Treatment } \\
\left(\mathrm{mg} \mathrm{ha} \mathbf{-}^{-1}\right)\end{array}$ & $\begin{array}{l}\text { Nitrogen } \\
(\%)\end{array}$ & $\begin{array}{l}\text { Phosphorus } \\
(\%)\end{array}$ & $\begin{array}{l}\text { Potassium } \\
(\%)\end{array}$ & $\begin{array}{l}\text { Calcium } \\
(\%)\end{array}$ & $\begin{array}{l}\text { Magnesium } \\
(\%)\end{array}$ \\
\hline $0.0 \mathrm{EFB}($ Control) & $1.69^{\mathrm{b}}$ & $0.22^{\mathrm{b}}$ & $2.47^{\mathrm{a}}$ & $0.41^{\mathrm{b}}$ & $0.42^{\mathrm{c}}$ \\
$7.5 \mathrm{EFB}$ & $2.31^{\mathrm{a}}$ & $0.31^{\mathrm{a}}$ & $2.71^{\mathrm{a}}$ & $1.11^{\mathrm{a}}$ & $0.65^{\mathrm{b}}$ \\
$15.0 \mathrm{EFB}$ & $2.31^{\mathrm{a}}$ & $0.35^{\mathrm{a}}$ & $2.84^{\mathrm{a}}$ & $1.14^{\mathrm{a}}$ & $0.82^{\mathrm{a}}$ \\
$22.5 \mathrm{EFB}$ & $2.41^{\mathrm{a}}$ & $0.37^{\mathrm{a}}$ & $2.82^{\mathrm{a}}$ & $1.13^{\mathrm{a}}$ & $0.65^{\mathrm{b}}$ \\
$7.5 \mathrm{CM}$ & $2.28^{\mathrm{a}}$ & $0.32^{\mathrm{a}}$ & $2.68^{\mathrm{a}}$ & $1.25^{\mathrm{a}}$ & $0.63^{\mathrm{b}}$ \\
\hline
\end{tabular}

Different letters in a column indicate significant difference at $P \leq 0.05$ by LSD; EFB= empty fruit bunches, $C M=$ chicken manure, DAT= days after transplanting

Table 4 : Effect of EFB compost rate and chicken manure on chemical properties changes in experimental plot at $60 \mathrm{DAT}$

\begin{tabular}{|c|c|c|c|c|c|c|c|c|c|}
\hline $\begin{array}{l}\text { Treatment } \\
\left(\mathrm{mg} \mathrm{ha}^{-1}\right)\end{array}$ & $\begin{array}{l}\text { Total carbon } \\
(\%)\end{array}$ & $\begin{array}{l}\text { Total nitrogen } \\
(\%)\end{array}$ & $\begin{array}{l}\mathrm{NH}_{4}-\mathrm{N} \text { (mg } \\
\mathrm{kg}^{-1} \text { soil) }\end{array}$ & $\begin{array}{l}\mathrm{NO}_{3}-\mathrm{N} \text { (mg } \\
\mathrm{kg}^{-1} \text { soil) }\end{array}$ & $\begin{array}{l}\text { Extractable } \\
\mathrm{P}(\mathrm{ppm})\end{array}$ & $\begin{array}{l}\text { Exchangeable } \\
\mathrm{K}(\mathrm{ppm})\end{array}$ & $\begin{array}{l}\text { Exchangeable } \\
\mathrm{Ca}\left(\mathrm{g} \mathrm{kg}^{-1} \text { soil) }\right.\end{array}$ & $\begin{array}{l}\text { Exchangeable } \\
\mathrm{Mg}\left(\mathrm{g} \mathrm{kg}^{-1} \text { soil) }\right.\end{array}$ & $\begin{array}{l}\text { Soil } \\
\text { pH }\end{array}$ \\
\hline $0.0 \mathrm{EFB}$ & 1.06 & $0.77 c$ & $12.51 \mathrm{~b}$ & $15.19 d$ & 112 & 13 & $0.30 \mathrm{~d}$ & $0.08 d$ & $5.85 b$ \\
\hline 7.5EFB & $1.37 \mathrm{ac}$ & $0.91 b$ & $15.77 a$ & $19.68 b$ & $281.13 c$ & $235.63 b$ & $0.60 c$ & $0.15 c$ & $6.62 a$ \\
\hline 15.0 EFB & $1.60 \mathrm{a}$ & $1.04 a b$ & $15.85 a$ & $22.26 \mathrm{a}$ & $414.83 b$ & $318.70 \mathrm{a}$ & $1.08 \mathrm{a}$ & $0.28 a$ & $6.79 \mathrm{a}$ \\
\hline 22.5 EFB & $1.45 a b$ & $1.11 \mathrm{a}$ & $16.06 \mathrm{a}$ & $23.69 a$ & $606.87 a$ & $356.33 a$ & $0.87 a b$ & $0.24 a b$ & $6.91 \mathrm{a}$ \\
\hline $7.5 \mathrm{CM}$ & $1.08 b c$ & $0.90 \mathrm{~b}$ & $13.37 b$ & $17.20 \mathrm{c}$ & $284.27 \mathrm{c}$ & $192.87 b$ & $0.68 b c$ & $0.19 b c$ & $6.56 \mathrm{a}$ \\
\hline
\end{tabular}

Different letters in a column indicate significant difference at $\mathrm{P} \leq 0.05$ by LSD; $E F B=$ empty fruit bunches, $C M=$ chicken manure, DAT= days after transplanting

Table 5 : Effect of EFB compost rate and chicken manure on microbial population changes in experimental plot at 60 DAT

\begin{tabular}{llll}
\hline $\begin{array}{l}\text { Treatments } \\
\mathrm{mg} \mathrm{ha}^{-1}\end{array}$ & $\begin{array}{l}\text { Bacteria } \\
\log 10 \mathrm{cfug}^{-1}\end{array}$ & $\begin{array}{l}\text { Fungal } \\
\log 10 \mathrm{cfu} \mathrm{g}^{-1}\end{array}$ & $\begin{array}{l}\text { Trichoderma } \\
\log 10 \mathrm{cfu}^{-1}\end{array}$ \\
\hline $0.0 \mathrm{EFB}$ & $8.34 \mathrm{c}$ & $5.05 \mathrm{c}$ & $2.96 \mathrm{~d}$ \\
$7.5 \mathrm{EFB}$ & $8.62 \mathrm{~b}$ & $5.17 \mathrm{~b}$ & $3.65 \mathrm{~b}$ \\
$15.0 \mathrm{EFB}$ & $8.66 \mathrm{~b}$ & $5.21 \mathrm{~b}$ & $3.68 \mathrm{~b}$ \\
$22.5 \mathrm{EFB}$ & $8.96 \mathrm{a}$ & $5.40 \mathrm{a}$ & $3.92 \mathrm{a}$ \\
$7.5 \mathrm{CM}$ & $8.63 \mathrm{~b}$ & $5.23 \mathrm{~b}$ & $3.41 \mathrm{c}$ \\
\hline
\end{tabular}

Different letters in a column indicate significant difference at $P \leq 0.05$ by LSD; EFB= empty fruit bunches, $C M=$ chicken manure, DAT= days after transplanting

was found in soil receiving $15.0 \mathrm{mg} \mathrm{ha}^{-1} \mathrm{EFB}$ compost, closely followed by $22.5 \mathrm{mg} \mathrm{ha}^{-1} \mathrm{EFB}$ compost rate. There was a significant $(\mathrm{P} \leq 0.05)$ effect of EFB compost and chicken manure on exchangeable $\mathrm{Mg}$ content and $\mathrm{pH}$ in soil as compared to control (Table 4).

In the present study, it was found that the application of EFB compost increased the availability of primary nutrients ( $N, P$, and $\mathrm{K}$ ), as well as $\mathrm{Ca}$ and $\mathrm{Mg}$ in soil. The increase in nutrients was due to the presence of nutrients in EFB compost. According to Guo et al., 2016, compost increases organic matter content, total $\mathrm{N}$, available $\mathrm{P}$, exchangeable $\mathrm{K}$, available water content, and porosity of soil as compared to control. They also added that compost amended plots showed more root growth near the soil surface and top soil. Better structural condition of organic manure amended soil is associated with decreased bulk density and increased porosity and hydraulic conductivity of soil (Guo et al., 2016). The results of the study is consistent with the findings of Toumpeli et al. (2013) who stated that compost (156 mg ha-1) prepared from Phragmite saustralis increased the availability of $\mathrm{N}, \mathrm{P}, \mathrm{Ca}$ and $\mathrm{Mg}$ concentrations, macro-aggregate stability and reduced clay dispersion in soil which enhanced tomato var. Santorini production in low input agriculture farming system.

Soil application of EFB compost and chicken manure increased soil pH (Alexander, 2001). Depending on the $\mathrm{pH}$ of compost and native soil, compost addition may raise or lower the soil pH. Addition of neutral or slightly alkaline compost to an acidic soil increase soil $\mathrm{pH}$, if added in appropriate quantities. In the present study, pH of EFB compost was slightly alkaline (8.05). Soil $\mathrm{pH}$ is one of the most important characteristics that may influence other properties (Bedada et al., 2016). It may affect the 
solubility of mineral and therefore, it governs several soil processes. It influences soil chemical and biochemical reactions. Soil reaction may affect plant growth directly or indirectly because it affects the solubility and availability of plant nutrients. It influences plant growth by affecting the activity of beneficial microorganisms. The rise in $\mathrm{pH}$ can be partly attributed to accumulation of basic cations and subsequent neutralization of protons in the root by anions (mainly $\mathrm{HCO}_{3}{ }_{3}^{-}$and $\mathrm{CO}_{3}{ }^{2}$ ), which accompany the cations in the water flow in the roots (Abujabhah etal., 2016).

Total bacterial, fungal and Trichoderma population in soil was found to be significantly $(P \leq 0.05)$ affected by the application of EFB compost and chicken manure (Table 5).Trichoderma population was found to increase with the application of EFB compost. The use of EFB compost containing Trichoderma might increase Trichoderma population in soil. Trichoderma is well known for its involvement in decomposition of organic matter (Kausar et al., 2014). Apart from that, Trichoderma possess the ability to solubilize plant nutrients and exhibit plant-growth promoting activity (Altomore et al., 1999). Microbial infused rice straw compost carries microbial population which colonizes rhizosphere of plants protecting them from diseases by competing for nutrients and infection sites or by production of antifungal compounds that can improve plant growth (Compant et al., 2005; Kausar et al., 2014). In addition, compost helps microorganisms to produce gummy substances that build good soil structure. These polysaccharides of microbial metabolism improve aggregate stability and soil properties. Compost stimulates symbiotic association of different microorganisms and plays significant role in transferring certain nutrients from soil to plants (Russo and Perkins-Veazie, 2010). Microorganisms have the ability to convert nutritionally important elements from unavailable to available forms through biological processes and also inhibit phytopathogens in soil by increasing the beneficial microorganisms, metabolites, hormones, and nutrients (Vessey, 2003; Jilani et al., 2007).

In conclusion, the results of this experiment showed that EFB compost @15.0 $\mathrm{mg} \mathrm{ha}^{-1}$ gave optimum plant growth, nutrient uptake and disease suppression, thus indicating its suitability for tomato cultivation under low input farming system.

\section{Acknowledgment}

This study was financially supported by the Geran Universiti Putra Malaysia (Vot. No. 9406900).

\section{References}

Abujabhah, I. S. , S. A. Bound, R. Doyle and J. P. Bowman: Effects of biochar and compost amendments on soil physico-chemical properties and the total community within a temperate agricultural soil. Appl. Soil Ecol., 98, 243-253 (2016).

Alexander, R.:Trichoderma compost fungus activator powder. Online at
http://-pcarrd.dost.gov.ph/philorganic/Technologies/organic\%20 inputs.pdf (Accessed on 3rd March, 2013) (2004).

Altomore, C., W.A. Norvell, T. Bjorkman and G.E. Harman: Solubilization of phosphates and micronutrients by the plant-growth-promoting and biocontrol fungus Trichoderma harzianum Rifai. Appl. Environ. Microb., 65, 2926-2933 (1999).

Ayoub, A.T.: Fertilizers and the environment. Nut. Cyc. Agroeco., 55, 117-121 (1999).

Bedada, W., M. Lemenih and E. Karltun: Soil nutrient build-up, input interaction effects and plot level $\mathrm{N}$ and $\mathrm{P}$ balances under long-term addition of compost and NP fertilizer. Agric. Ecos. Environ., 218, 220-231 (2016).

Biradar, P.M. and V.A. Biradar: Influence of organic wastes on the biology of epigeic earthworm, Perionyx excavatus during different seasons. J. Environ. Biol., 36, 105-1100 (2015).

Cassman, K.G., S. Peng, D.C. Olk, J.K. Ladha, W. Reichardt, A. Dobermann and U. Singh: Opportunities for increased nitrogenuse efficiency from improved resource management in irrigated rice systems. Field Crops Res., 56, 7-39 (1998).

Chiew, L.K.: From waste to fertilizer. Online at http://thestar.com.my, The Star Online, Accessed on 1 April 2009 (2004).

Compant, S., B. Duffy, J. Nowak, C. Cl'ement and E.A. Barka: Use of plant growth-promoting bacteria for biocontrol of plant diseases: Principles, mechanisms of action, and future prospects. Appl. Environ. Microb., 71, 4951-4959 (2005).

Erwan, M.R. Ismail, M. Sariah, H.M. Saud, S.H. Habib, H. Kausar and L. Naher: Effect of oil palm frond compost amended coconut coir dust soilless growing media on growth and yield of cauliflower. Int. J. Agric. Biol., 15, 731-736 (2013).

Good, A.G. and P.H. Beatty: Fertilizing nature: A tragedy of excess in the commons. PLoS Biol., 9, e1001124 (2011).

Guo, L., G. Wu, Y. Li, C. Li, W. Liu, J. Meng, H. Liu, X. Yu and G. Jiang: Effects of cattle manure compost combined with chemical fertilizer on topsoil organic matter, bulk density and earthworm activity in a wheatmaize rotation system in Eastern China. Soil Till. Res., 156,140-147 (2016).

Hylander, L.D. and A. Noriharu: Nutrient distribution around roots of brachiaria, maize, sorghum, and upland rice in an andisol. Soil Sci. Plant Nutr., 45, 617-626 (1999).

Jilani, G., A. Akram, R.M. Ali, F.Y. Hafeez, I.H. Shamsi, A.N. Chaudhry, and A.G. Chaudhry: Enhancing crop growth, nutrients availability, economics and beneficial rhizospher emicroflora through organic and biofertilizers. Ann. Microb., 57, 177-183, (2007).

Kausar, H., M.R. Ismail, H.M. Saud, M. Sariah, R. Othman and S.H. Habib: Efficacy of microbial infused rice straw compost on plant growth promotion and induction of disease resistance in chilli. Compost Sci. Util., 22, 1-9 (2014).

Kausar, H., M. Sariah, H.M. Saud, M.Z. Alam and M.R. Ismail: Development of compatible lignocellulolytic fungal consortium for rapid composting of rice straw. Int. Biodeter. Biodegr., 64, 594-600 (2010).

Kausar, H., M. Sariah, H.M. Saud, M.Z. Alam and M.R. Ismail: Isolation and screening of potential actinobacteria for rapid composting of rice straw. Biodegradation, 22, 367-375 (2011).

Killi, D. and Y. Kavdır: Effects of olive solid waste and olive solid waste compost application on soil properties and growth of solanum lycopersicum. Int. Biodeter. Biodegr., 82, 157-165 (2013).

Lal, R.: Conservation tillage in the tropics for soil carbon sequestration. $15^{\text {th }}$ International Soil Tillage Research Organization Conference 
(ISTRO). Fort Worth, Dallace, Tx, USA (2000).

MARDI, Seed catalogue: A listing of recommended varieties for vegetables, flowers, field crops and species. Division of Horticulture, MARDI, Serdang (1990).

Marinari, S., G. Masciandaro, B. Ceccanti and S. Grego: Influence of organic and mineral fertilisers on soil biological and physical properties. Biores. Technol., 72, 9-17 (2000).

Mohammad N., M.Z. Alam, N.A. Kabbashi and A. Ahsan: Effective composting of oil palm industrial waste by filamentous fungi: $A$ review. Resour. Conserv. Recy., 58, 69-78 (2012).

Mohammadi, K., G. Heidari, M.T.K. Nezhad, S. Ghamari and Y. Sohrabi: Contrasting soil microbial responses to fertilization and tillage systems in canola rhizosphere. Saudi J. Biol. Sci., 19, 377-383 (2012).

Mokhtari, S., M.R. Ismail, H. Kausar, M.H. Musa, P.E.M. Wahab, Z. Berahim, M.H. Omar and S.H. Habib: Use of organic enrichment as additives in coconut coir dust on development of tomato in soilless culture. Compost Sci. Util., 21, 16-21 (2013).

Ouedraogo, E., A. Mando and N.P. Zombre: Use of compost to improve soil properties and crop productivity under low input agricultural system in WestAfrica. Agric. Ecos. Environ., 84, 259-266 (2001).

Parrado, J., J. Bautista, E.J. Romero, A.M. Garcia-Martinez, V. Friaza and M. Tejada: Production of a carob enzymatic extract: potential use as a biofertilizer. Biores. Technol., 99, 2312-2318 (2008).

Pinamonti, F. and L. Sicher: Compost utilization in horticultural cropping systems. In: Compost utilization in horticultural cropping systems (Eds.: P.J. Stoffella and B.A. Kahn). Lewis Publishers, Boca Raton, London, New York, Washington DC, pp. 177-200 (2001).

Pinheiro, B.D.S., E.D.M.D. Castro and C.M. Guimaraes: Sustainability and profitability of aerobic rice production in Brazil. Field Crops Res., 97, 34-42 (2005).

Prasad, S.K.: Effect of soil amendment on nematodes associated with wheat followed by moong and maize. Indian J. Entom., 34, 307311 (1997).

Russo, V.M. and P. Perkins-Veazie: Yield and nutrient content of bell pepper pods from plants developed from seedlings inoculated, or not, with microorganisms. Hort. Sci., 45, 352-358(2010).

Sharifuddin, H.A.H. and R.F.P. Dynoot: Basic guide to soil and plant analysis. Soil Science Department. Tech. Bull. Fac. Agric., UPM Serdang, p. 48 (1981).

Tan, Y.H. and M.N. Wahab: Extracellular enzyme production during anamorphic growth in the edible mushroom, Pleurotus sajor-caju. World J. Microbiol. Biotechnol., 13, 613-617(1997).

Thambirajah, J.J., M.D. Zulkali and M.A. Hashim: Microbiological and biochemical changes during the composting of oil palm emptyfruit-bunches. Effect of nitrogen supplementation on the substrate. Biores. Technol., 52,133-144 (1995).

Toumpeli, A., A.K. Pavlatou-Ve, S.K. Kostopoulou, A.P. Mamolos, A.S. Siomos and K.L. Kalburtji: Composting Phragmites australis Cav. plant material and compost effects on soil and tomato (Lycopersicon esculentum Mill.) growth. J. Environ. Manage., 128, 243-251 (2013).

Vessey, J.K.: Plant growth promoting rhizobacteria as biofertilizers. Plant Soil, 255, 571-586 (2003).

Wang, J.F., P. Hanson and J.A. Barnes: Worldwide evaluation of an international set of resistance sources to bacterial wilt in tomato. Bacterial Wilt Disease molecular and ecological aspects (Eds.: P. Prior, C. Allen and J. Alphinstone). Part IV, pp. 269-275 (1998).

Yang, X.M., C.F. Drury, W.D. Reynolds and C.S. Tan: Nitrogen mineralization and uptake by ryegrass in a clay loam soil amended with composts or liquid pig manure. Can. J. Soil Sci., 84, 11-17 (2004).

Yusri, A., M.R. Awang, M. Omar, A. Hashim, T. Kume and S. Hashimoto: Biodegradation of oil palm empty fruit bunch by composite microorganisms. J. Sain. Nuk. Mala., 16, 91-105 (1998).

Zhai, Z., D.L. Ehret, T. Forge, T. Helmer, W. Lin, M. Dorais and A.P. Papadopoulos: Soil management, fertilization, and irrigation organic fertilizers for greenhouse tomatoes: Productivity and substrate microbiology. Hort. Sci., 44, 800-809 (2009).

Zheng, Z. and K. Shetty: Solid-state production of beneficial fungi on apple processing wastes using glucosamine as the indicator of growth. J. Agric. Food Chem., 46, 783-787 (1998). 